PEDAGÓGUSKÉPZÉS, 10-11 (39-40), 2012-2013. 203-206.

\title{
A MINŐSÉGBIZTOSÍTÁS ÉS A PEDAGÓGUSKÉPZÉS LEHETSÉGES ÚTJAI
}

\author{
PREKOPA DóRA \\ az Eötvös Loránd Tudományegyetem Pedagógiai és Pszichológiai Kar \\ Neveléstudományi Doktori Iskolájának \\ hallgatója \\ prekopadora@gmail.com
}

A pedagógusképzésre, valamint a képzés minőségének biztosítására fokozott figyelmet szenteltek a különböző országok neveléstudomány kutatói és döntéshozói az elmúlt évtizedekben. Abban minden ország egyetért, hogy folyamatos fejlődésre van szükség, így a téma napjainkban is aktuális. Ezt igazolja Dennis Shirley, a Bostoni Egyetem professzorának gondolata is - amely más ajánlásokkal együtt a könyv hátoldalán olvasható - miszerint „minden pedagógus és döntéshozó számára kötelező olvasmány, aki az elkövetkezendő években igazi és fenntartható fejlődést kíván elérni az iskoláinkban.” A hazai olvasók számára azért is érdemes kézbe venni a könyvet, mert a 2013 szeptemberében induló új, osztatlan tanárképzés összehasonlítására ad lehetőséget más nemzetek pedagógusképzési rendszerével.

Amikor az olvasó először kezébe veszi a könyvet, nem biztos, hogy el tudja dönteni, mit is ábrázol a borítófotó. Némi segítségképpen ez egy út, de az iránya, vége nem látható, pontosan úgy, ahogyan a pedagógusképzés és a minőségbiztosítás folyamata sem, mivel az többféleképpen megvalósítható. A könyvben ilyen utakat ismerhetünk meg, különböző országok fejlödését e területen.

A könyv szerkesztői Judith Harford, a Dublini Egyetem tanárképzésének kutatásvezetője, valamint társ-koordinátora az Európai Pedagógusképzés Politikai Hálózatnak és tagja az Európai Oktatáskutatók Szövetségének. Brian Hudson a Dundee Egyetem neveléstudomány professzora, dékán helyettese az Iskolai oktatás, Szociális munka és Közösségi oktatás Karnak, illetve Hannele Niemi, a Helsinki Egyetem neveléstudomány professzora, akinek 2005-ben magyarul is megjelent két írása ${ }^{1}$ - egyik társszerzőként - a Pedagógusképzés címü folyóiratban. Összesen tizenegy szerző vagy szerzőpáros írásait olvashatjuk, akik az egyes országok minőségbiztosítási és tanárképzési rendszereinek szakértői. A szerzők és főbb munkásságuk igényes mó-

\footnotetext{
${ }^{1}$ Niemi H. (2005): Aktív tanulás - avagy egy kívánatos kultúraváltás a tanárképzésben és az iskolákban. Pedagógusképzés, 3. sz. 87-116. o. illetve Niemi H. és Jakku-Sihvonen R. (2005): Megelözve a Bologna folyamatot - 30 év kutatás alapú tanárképzés Finnnországban. Pedagógusképzés, 2. sz. 93-111. o.
} 
don bemutatásra kerül a könyv végén, ezzel megkönnyítve a további tájékozódást a téma iránt érdeklődők számára.

A könyv nyelvezetét tekintve alapvetően könnyen olvasható, gazdagságát és részletességét a 273 oldalnyi terjedelem is jelzi. A mü egy rövid Tudnivalók címü rész után Bevezetővel kezdődik, melyben röviden összefoglalják az egyes tanulmányokat, illetve bemutatják a könyv azon kulcsüzenetét, miszerint nem a hagyományosnak mondható minőségirányítást, minőségbiztosítást, hanem a minőség kultúráját lenne szükséges támogatni. A pontosításra azért van szükség, mert a minőség kultúrája nem egy top-down szemléletet tükröz, hanem a rendszer, szervezet tagjainak együttmüködését sugallja (Ehler, 2009 idézi Niemi, Harford és Hudson,2012).

A könyv két fő tartalmi részre tagolódik, az első rész három tanulmányt foglal magában. Sheelagh Drudy munkájában amellett érvel, hogy az európai tanárképzés minőségpolitikájában nem csak az állandó teljesítménykényszerre, hanem a gondoskodás, társadalmi igazságosság és szolidaritás etikájára kellene fókuszálni, ami elmélyítené a társadalmi jól-létet és a demokráciát (30. o.). A második tanulmányban Kay Livingston írja le gondolatait, miszerint a pedagógusképzésben még nem érvényesült a konstruktív, önszabályozó, aktív és társas tanulás. Ez súlyos probléma, ugyanis a hagyományos egyetemi előadások, szemináriumok nem biztosítják, hogy a tanár szakos hallgatók átgondolják diákként átélt tapasztalataikat, nézeteiket. A szerző a szakmai életpálya fejlődés szükségességét látja, amely támogatást adhatna a pedagógusoknak, hogy magabiztosságukban, önértékelö készségeikben és önreflexióikban fejlödhessenek. A harmadik tanulmányban Hannele Niemi és Stephen Kemmis a kommunikatív értékelés folyamatát ismertetik. Finnországban azért alkalmazzák az értékelés ezen módszerét, hogy elösegítsék a különböző szintek, szereplők - kultúra, társadalom és az egyén - közötti interakció megteremtését. A kommunikatív értékelés folyamata három részben történik 1) feltételezések feltárása, amelyek gátolhatnák a további tanulási folyamatot 2) tervezés, amely során a jelenlegi helyzetet felmérik és a következő lépéseket megtervezik és 3) kommunikáció és partneri kapcsolatok kialakítása.

A második fejezetben betekintést nyerhetünk több ország tanárképzési és minőségbiztosítási rendszerébe, felsorolásszerüen a bemutatott országok: Svédország, Szingapúr, Amerika, Finnország, Szlovénia, Írország és Skócia. A második fejezet célja nem a megvizsgált országok rendszereinek rangsorolása, hanem egy széles spektrumú, többféle megvalósítás bemutatása. Finnországra sok szem szegeződik a PISA vizsgálaton elért előkelő eredményeik miatt, egyenesen finn csodáról olvasni számos szakirodalomban, így természetesen ebben a könyvben is bemutatásra kerül az ország. A finn felsőoktatásban három szintet különböztetnek meg és a pedagógusképzésre vonatkozóan a következő értékelések léteznek: 1) nemzeti, amely során auditok és egyéb külső értékelések zajlanak. A fó értékelés hatéves ciklusokban történik, amelynek célja az erősségekre való rávilágítás, a stratégia tudatosítása. 2) az intézményi szint. Az első pontban említett audit minden egyetemnek megadja 
azt a szabadságot, hogy saját minőségbiztosítási rendszert dolgozzon ki a minőség kultúrája érdekében (162-164. o.). 2010-ben kérdőíves módszerrel vizsgálták az Oului és a Helsinki Egyetem tanár szakos hallgatóinak véleményét a képzés minőségéről. 3) intézet vagy program szinten a közvetlenül a diákok tanulásának fejlödését veszik figyelembe. A szerzők a Helsinki Egyetem gyakorlatát mutatják be, ahol egy akadémiai év alatt különböző aktorok - például intézeti munkatársak, diákok - háromszor szerveznek közös találkozót, melyek során közösen megvitatják többek között a program célját, kitüzéseit, értékelését (175. o.). Ezen a szinten is kérdőíves módszerrel vizsgálják hallgatók véleményét, melyben a vizsgálat kiterjed a tanítás minőségére, a személyes fejlődés elősegítésére is (177. o.). A finn rendszer fontos eleme, hogy a három fö szint nem egymástól elkülönülve müködik, hanem együttmüködnek, szoros interakcióban állnak egymással.

A könyv külön értékének tekinthető, hogy nem csak európai példákat tár az olvasó elé. Szingapúrban nagyon élesen látják, hogy az oktatás a tanárok minőségétől függ, így nagy hangsúlyt fektetnek a pedagógusképzésre és annak minőségére. A tanárképzés kulcsintézménye a National Institute of Education - továbbiakban NIE -, mely a minőség menedzselését szolgáló rendszert alakított ki. A tanárképzés során egyaránt figyelembe veszik a bemenetet, a folyamatot és a kimenetet, valamint céljuk nem csupán egy minimum szint elérése, hanem a folyamatos fejlődés. Együttesen alkalmazzák a formatív és a szummatív értékelést, az előbbi a fejlődést, az utóbbi az elszámoltathatóságot alapozza meg. Úgy gondolják, hogy a különböző értékelési funkciók használata azért fontos, mert így biztosítható a minőség hosszú távú fenntartása (120. o.). A NIE rendszere öt modellen alapul annak érdekében, hogy több szereplő véleményét, javaslatát, aktivitásokat vehessenek figyelembe a folyamatos fejlesztés érdekében (122. o.). Ebből a fejezetből hiányolhatjuk Szingapúr pedagógusképzésének pontosabb ismertetését, mert inkább a minőségbiztosítási rendszer bemutatására fókuszálnak a szerzők. Az Amerikai Egyesült Államok pedagógusképzési és minőségbiztosítási rendszerének vizsgálata nem csak azért érdekes, mert nem európai, hanem mert például a szingapúri példával ellentétben igen változatos. Alapvetően a tanár szakos hallgatók kétféle út közül választhatnak Amerikában. Elvégezhetnek egy négy vagy ötéves alapos képzést, amely BA és MA diplomát is ad, vagy választhatják az egy vagy kétéves képzést, amely csak MA diplomaszerzésre ad lehetöséget. A programok különböznek struktúrájukban, tartalmukban és minőségükben, illetve az 50 államban másképpen szabályozzák őket (132. o.). A nagy eltérések alapján joggal kérdőjelezhető meg az Egyesült Államok pedagógusképzésének minősége, ennek kezelését mutatja be a szerző.

A könyv részletesen ismerteti a legújabb pedagógusképzésben és minőségbiztosításban zajló globális trendeket, nemzetenkénti eltéréseket, sajátosságokat. „A tanítás minősége a legfontosabb faktor, ami befolyásolja a diákok tanulását.” (115. o.), éppen ezért a tanárképzés és a képzés minőségének biztosítása, folyamatos fejlesztése a cél. Azért (is) célszerü kezünkbe venni a könyvet, hogy más, gyakorlottabb 
országoktól, eddigi tapasztalataikból tanulhassunk. Biztos, kész megoldást a könyv nem kínál és nem is ajánlhat, mert a megfelelő pedagógusképzési és minőségbiztosítási rendszert minden nemzetnek önmagának kell felépítenie, ehhez az elemeket csak eltanulhatjuk másoktól.

Harford J., Hudson B. and Niemi H. (2012, ed.): Quality Assurance and Teacher Education. International Challenges and Expectations. Vol. 6. Rethinking Education, Peter Lang, Oxford, Bern, Bruxelles, Frankfurt am Main, New York, Wien, 273 oldal 